\title{
LOGICAL AND RATIONAL COMPONENT OF MODERN EDUCATIONAL PROCESS
}

\author{
Nataliia Khanykina \\ ORCID iD 0000-0002-5920-9779 \\ $\mathrm{PhD}$ (Philology), Senior Researcher, \\ Scientific Research Laboratory of Education, \\ Borys Grinchenko Kyiv University, \\ 13-B, Marshal Timoshenko St., Kyiv, Ukraine, \\ n.khanykina@kubg.edu.ua
}

\section{Tetiana Bondar}

ORCID iD 0000-0001-6796-0063

$\mathrm{PhD}$ (Pedagogy), Associate Professor,

Associate Professor of the Department of Philosophy,

Borys Grinchenko Kyiv University,

13-B, Marshal Timoshenko St., Kyiv, Ukraine,

t.bondar@kubg.edu.ua

https://doi.org/10.28925/2518-7635.2020.5.4

\section{ABSTRACT}

The formation of a new historical type of personality requires appropriate changes in the content of education, means of the set tasks' implementation and the organization of the education system itself. Achieving this goal is impossible without the formation of a high intellectual culture of a person and the ability of the individual to its further continuous improvement. However, nowadays the role and place of cultural and anthropological factors, as well as logical and rational ones, are often underestimated in the modernization process of the society.

The proposed article emphasizes the need to reveal the role of logical and rational component as a necessary part of the modern educational process and the way to improve mental culture through education.

It is noted that the level of modern culture of thinking, rational reasoning, the ability to conduct constructive dialogues has fallen significantly. The inability and unwillingness of many members of society to analyze situations critically, lack of skills to express theiropinions consistently and reasonably, to persuade theirfellow citizens in a rational and logical way can lead to barbarism. The results of hours' reduction in logic disciplines at the University are given. This fact is reflected in the inability of students to establish the relationship of genus and species, causal relationships between objects and phenomena, to make classifications. The need for logic knowledge, which helps to identify false information, to reveal logical errors, is indicated. 
Emphasis is placed on the importance of high appreciation of rationality. It has its origins in antiquity and finds its expression in ancient philosophy. Ancient philosophers proceeded from the fact that the world can be comprehended only with the help of reason and rational methods, based on the power of persuasion, thought.

The role of language as a cultural phenomenon is emphasized. Cultural phenomenon in combination with consciousness, mental and cognitive processes is impossible without the rational use of the laws of logic.

Key words: educational process; educational ideal; content of education; culture of thinking; logic, logical and rational means

(C) Nataliia Khanykina, Tetiana Bondar, 2020

\section{INTRODUCTION}

The need to form a new historical type of personality determines the nature of changes in the process of human socialization. The new tasks and the new goals require adequate changes in the content of education, means of the set tasks' implementation and the organization of the education system itself.

Awareness of the essence of social and cultural changes of the individual, adequate to modern social processes, and ways of its transformation eventually accumulate in the so-called "educational ideal" that would meet the demands of modern society. This new ideal, as a category of pedagogical science, should become the core of the educational policy of the state, its social order in school (the Law of Ukraine "On Education", p. 44).

Conceptually clear reproduction of personality characteristics, which is adequate in the social and cultural dimension to the requirements of this society, is the basis for the formation of the educational ideal. The transformation of Ukrainian society into a state governed by the rule of law, leads to the consolidation of this ideal and the means of its achieving at the legislative level. The Law on Education defines the purpose of education and its place in modern Ukrainian society. "The purpose of education is the comprehensive development of human as a person and the highest value of society, the development of his talents, mental and physical abilities, formation of citizens capable of conscious social choice, enrichment of intellectual, creative, cultural potential of the people, raising the educational level of the people, providing the national economy with highly qualified specialists" (Volkov, 1971, p. 168). However, such definitions, without being specified through the means of achieving the goal and certain schemes of their application, are purely declarative. Unfortunately, we live among other realities. The peculiarity of modern social consciousness is the underestimation of the place and role of cultural and anthropological, and foremost logical and rational factors in the modernization process of society. A similar situation has developed not only in our country, but also in other post-Soviet countries. However, concerns about this are expressed only by scientists, mainly in Russia 
(for example, G. Tulchinsky, G. Sorina, V. Meskov, A. Subbotin, V. Bryushinkin and etc.). In Ukraine, there are only a few works of scientists, philosophers and educators who try to draw public attention to the rationality of reasoning (V. Titov, O. Tyaglo, O. Bandurka), in particular, the role of critical thinking and means of its formation and development. Achieving this goal is impossible without the formation of a high intellectual culture of a person and the ability of the individual to its further continuous improvement.

The purpose of the proposed article is to reveal the role of the logical and rational component as a necessary unit of the modern educational process and to comprehend the ways to improve the mental culture by means of education.

Today, a wave of alogism and irrationalism has swept our culture. Unfortunately, the fact of the decline in the level of thinking, rational reasoning and the ability to conduct constructive dialogues is indisputable. The inability and unwillingness of many members of society to analyze certain situations critically, the lack of skills to express their own opinions consistently and reasonably, to persuade their fellow citizens in a rational and logical way in politics and other spheres of public life - is the path from civilization to barbarism. Such dogmatic thinking, absolute trust in authority and the search for these authorities, real or imagined, is a characteristic feature of a human in a totalitarian society, ready to carry out the orders of his leaders exactly and unquestioningly. This is an atavism of the totalitarian mentality.

In modern society, controversy dominates the debate, because the goal is not to find an optimal, rational solution, but to win the dispute. The desire to be understood and to understand oneself is not in sight. Moreover, an attempt at clear reasoning or simply clear, coherent language provokes aggression. We can talk about the terrible triumph of logical ignorance, the absence of any logical culture - in everyday life, in business, in political life. Verbosity in the absence of argumentation, in fact, inability to think concretely, irresponsible decisions, inability to agree laws, inability and unwillingness to seek and determine the meaning of concepts that reflect the essence of certain objects and phenomena, inability to define the subject of agreement or dispute, their own position. Logic, which should guarantee understanding, rational thinking, communication and action, is not only perceived, but even denied, rejected.

However, as V. Lektorskiy rightly emphasizes "Rationality is one of the cultural values, and without reliance on it a person would not be able to act and learn. Because action involves a rational choice of goals and selection of the most effective means of their implementation and obtaining true results in cognition is impossible without the use of rational methods. Extremely high assessment of rationality in antiquity found its expression in ancient philosophy. In spite of all the differences between the philosophers of that time, the majority concluded that the world can be comprehended with the help of reason and rational methods. The ability of rational argumentation was indispensable in discussing social problems." (Kuzmin, Artemenko, 2006, p. 26). 
The problem of the role of logical culture in the educational process is not new. The importance of logic as a necessary prerequisite for teaching and education was emphasized by such well-known teachers as John Amos Comenius, Konstantin Ushinsky, Vasyl Sukhomlynsky. Issues of teaching logic and ways of forming and improving the culture of thinking are discussed at scientific and practical conferences, in publications of specialists. Unfortunately, the modern educational reforms and their original interpretation by educational institutions are not aimed at achieving the legally established goal, but also contribute to the opposite results. Some theorists of education believe that first of all the school should develop not critical thinking, but aesthetic abilities, not the ability to argue their position, but affectivity and imagination. Since the teacher, from this point of view, embodies the repressive norms of culture, in particular, the repressive norms of rational reasoning, his authority must be significantly reduced.

Logic, which was one of the main sciences of the medieval education system, in our time of the information society has become an academic discipline of choice. The situation became absurd when at our university it was included in the number of disciplines of the student's choice, along with such as "Business Etiquette", "Kyiv Studies", "Philosophy of Love", "Psychology of Intersexual Relations", "Ethics of Business Communication", etc. As a result, only about $10 \%$ of students (future philologists, translators, journalists, historians, psychologists, preschool teachers and primary school teachers) study logic. The results were not long in coming. Students often do not know how to establish the relationship of genus and species, causal and consequential relationships between objects and phenomena, to classify.

It is an indisputable fact that the ability to operate with concepts plays an important role in the learning process. The process of defining concepts is especially important. It is not only difficult but almost impossible to master the basics of science thoroughly and deeply without a clear mastery of the basic concepts of any science and discipline, as well as the whole system of interconnected concepts of a particular subject or science. Teachers of professionally oriented disciplines do not pay due attention to the formation of the conceptual apparatus of students, as a result, they perceive the content of concepts on an intuitive level mainly. For example, answering the exam in Ukrainian literature on the question "Romanticism in T. Shevchenko's ballads" students simply retell the meaning of ballads, and cannot give a logically correct definition of "romanticism", to analyze works in accordance with the question.

Logic studies the laws and forms of thinking, and thinking is inextricably linked to language. It is impossible to master language well without knowledge of logic, because language is the materialization of thought, and incorrectly constructed reasoning will be similarly expressed in language. Grammar knowledge, which is initially formed spontaneously, is systematized later and honed throughout the school period and even in higher education institution (the so-called "language of professional communication", which, 
in our opinion, is an unjustified use of study time). "Philologists, first of all, need to know such logical categories as "sign", "meaning", "artificial language", "metalanguage", the relationship between the categories of grammar and logic" (Lektorskiy, 2012, p. 98).

Improving the culture of thinking remains a mostly spontaneous process, it is not given due attention. The fact that nowadays a lot is said about the culture of speech, culture of communication, food, clothing, political, legal culture, etc., and at the same time such concepts as "culture of thinking", "logical culture" occur only in a narrow circle of experts, is already a logical paradox. After all, the basis of any culture is the culture of thinking, and its level determines the level of all other "cultures". Students who do not have basic logical knowledge today will become teachers and tomorrow they will come to class or student audience to teach others. Will they be able to transfer knowledge, form skills and abilities in their students, influence the formation of their worldview? Obviously no. Since, the pedagogical process involves not only the transformation of knowledge that can be memorized and reproduced, but the formation of a holistic worldview, belief system. This cannot be achieved without understanding and explanation, aimed at achieving understanding as a result. Teaching logic is very important in the intellectual and moral development of the individual, because it is the foundation of any school discipline and any science (social, natural, technical). Today the problem of logical culture is urgent for education as never before. Continuous improvement of the level of logical culture is a necessary component of modern education.

The teaching of traditional logic should be aimed at fostering a culture of thinking in the process of pedagogical activity. It can be teaching of any discipline by all teachers (physicists, mathematicians, chemists, linguists, historians, etc.). Raising the level of mental culture will have positive results when it is done not only by teachers of logic, but in the teaching of each discipline, when each teacher has a high level of mental culture and constantly strives to improve it, when logic helps to learn educational material.

Nowadays, the task of rational construction of the learning process becomes especially important in the educational institutions. Extensive methods, which provide for the expansion of the amount of assimilated information, should give way to intensive methods, which provide for the rational selection of the most important information. A necessary condition for attracting new teaching methods is the development of logical culture of both teachers and students, mastering of methodology and methods of scientific knowledge, rational methods and techniques of evidence-based reasoning, the formation of creative thinking.

Logical culture is not innate. For its development it is necessary first of all to acquaint teachers and students of pedagogical educational institutions with the basics of logical science, which has accumulated theoretically sound methods and techniques of rational reasoning and argumentation. Teachers who have the basics of logical knowledge will be able to pass this knowledge 
and thinking skills to their students. Logic contributes to the formation of self-awareness, intellectual development of the individual, helps to form a scientific worldview. The successful solution of complex problems of teaching and educating young people largely depends on the teacher, on his intellectual level, professional skills and culture. The profession of a teacher requires constant creativity, tireless work of thought and improvement of its culture. To improve the training of teachers, it is necessary to introduce a course of logic in the curriculum, and also to expand its teaching, to increase the number of teaching hours and to improve the programs.

Information is better remembered if it is logically structured, systematized. Logical processing of information is much easier when a person has a high level of mental culture development. If knowledge is presented as a logically unstructured text, as an unsystematic set of facts - then we talk about mechanical memorization, which doesn't lead to the formation of a holistic view of the subject, and this information is usually quickly forgotten. Knowledge of logic helps to identify false information, to reveal logical errors.

Problems of the culture of thinking, ways and means of its formation in the educational process are posed and discussed in the works of Evald Ilyenkov, especially in his article "Our Schools Must Teach How to Think!", published in 1964 in the journal "Public Education". Nowadays this work doesn't lose its relevance. Doctrine of Evald Ilyenkov is becoming even more acute in modern conditions. In particular, this applies to Ukraine.

Conceptually clear reproduction of personality characteristics, which is adequate in the social and cultural dimension to the requirements of this society, is the basis for the formation of the educational ideal. It should be the criterion by which you can determine the degree of compliance of the problems in the field of education, the real needs of society. The transformation of Ukrainian society into a state governed by the rule of law, leads to the consolidation of this ideal and the means of its achieving at the legislative level.

The social mission of education is multifaceted. It is about improving social inequality, about inculcating citizenship standards, about contributing to culture and the economy, where it is the core of civilization. Education is the cultural center of society with its unchanging values, pedagogical experience and focus on education and preservation of its human origins.

The results of education should include, above all, the development of personality. The subjective side of social relations is the main generator of its development and modernization in the information society. This very fact is indisputable. Therefore, the very institutional and structural changes in Ukraine require the formation of new meaningful life orientations and new cultural abilities. This is the main task of the national education system. Similar challenges lead to a number of problems associated with the process of improving and modernizing the system itself. The main directions of modern national education development should be provided by the adequate ways, where solution and implementation of the set problems really coincide. According 
to the author, the determining means consist in the formation of high intellectual culture of the individual and his ability to further continuous improvement, scientific worldview, which would provide the ability to problematize ideas and generate the new ones, the systematic and critical thinking which lead to understanding and social interaction. "The culture of thinking is not just intelligence and "primitive" mind, but in some way developed, rich, cultivated mind. This is not a gift of nature and heredity, but a "gift" of society. And if so, then the question is natural: "how to learn the culture of thought? What is it?" - wrote G. Volkov (Aristotel, 1984, p. 12). Philosophical sciences play a leading role in solving the set tasks.

In recent years, there is an opinion that if the main purpose of the university is the training of future professionals in a particular field of activity, then the curriculum should be subordinated to this goal. Anything that is not aimed directly at training future professionals should be removed from the curriculum. Such considerations are the basis for reducing the number of hours devoted to the study of philosophy and philosophical disciplines in the universities. However, true science has always been associated with philosophy. Philosophy in the complex of all its sciences cultivates tolerance for other people's thoughts and a critical attitude to one's own views.

The desire for narrow professionalization of higher education expresses the tendency, which has long manifested itself in Western Europe and the United States, to transform the majority of the population into "onedimensional people" (G. Marcuse, in "people of crowds, masses" (José Ortega y Gasset), whose consciousness can be easily manipulated. Ultimately, it is a movement towards the establishment of a universally totalitarian society. Currently, brainwashing techniques, propaganda, advertising, the media are able to subdue the human mind completely, to instill any purpose and values, to awaken any feelings and attitudes to things and phenomena, to form the tastes and even more. Thus, in modern society not only the behavior but also the human consciousness is also controlled by the state or power elites. The history of mankind has never known such total control over person. Depriving the philosophy of influence on the worldview formation of the young generation and its intellectual culture will mean another important step towards complete spiritual slavery of human.

The history shows, that the level of logical culture and the authorities' attitude to it meets the demands of the social order and the nature of social processes. No wonder the formation of logic as a science occurred in ancient society primarily due to democracy. Democracy requires a government based not on coercion or the barbaric sword, but on the power of persuasion and thought.

Verbosity in the absence of argumentation, in fact, is inability to think concretely, which lead to irresponsible decisions, inability to agree laws, inability and unwillingness to seek and determine the meaning of concepts that reflect the essence of certain objects and phenomena, inability to define the subject of agreement or dispute, to define one's own position. Logic, which should 
guarantee understanding, rational thinking, communication and action, is not only perceived, but even denied, rejected.

The real social status of logic in our society at this stage of its development is unsatisfactory. Experience has shown that the transition from totalitarianism to democracy does not necessarily have real democracy as its end point. The atmosphere of fear for someone's position, conformism and social anemia contributes to the emergence of oligopoly.

Logical culture is unnecessary here. There is no question of the relationship between the declared and the desired, necessary and existing in real politics, legislation, large-scale economic projects and their implementation, in the field of education. Skepticism towards the declared political and legal, social and economic decisions is not accompanied by independent thinking and taking into account the logical consequences arising from the election promises. Society has an unsatisfactory "logical status". Our economists and politicians have not studied logic and have a fairly low level of logical culture. It is impossible to train a highly professional specialist without proper philosophical and logical education in any field, especially in the humanities. Take philology as an example. Any education has a purpose. A natural question arises: what is the purpose of philological education? The object of study is language here. As a result, we can hardly do without answering the question: what is language, when and why it occurs, how language belongs to consciousness, what is the role in the process of cognition in the social environment, how it affects and whether it affects the formation of personality, nation-building processes, etc.

The answers to these questions can be given by logical and philosophical reflection on language as a cultural phenomenon. Scientists for centuries have tried to give a philosophical understanding of this complex and even mysterious phenomenon to some extent. In the III century B.C. the famous ancient Greek philosopher Plato tried to give a philosophical understanding of language through Socrates in his dialogues, in particular in the dialogue "Cratylus". The phenomenon of language remains the subject of study by modern scientists.

\section{CONCLUSIONS}

We live in an era of rapid social change. Today, humanity has entered the phase of finding new strategies for civilizational development, the search for new values, when it becomes necessary to analyze the previous meanings of life that guide the development of civilization. To the eternal philosophical problems of existence, consciousness, meaning of life and others, the modern era has added a fundamentally new, never-before-existing problem of a single destiny of mankind and the preservation of life on Earth (Pavlov, 1984, p. 12). Recognition of the important role of unconscious motives in human life, the presence of cases of self-deception does not preclude understanding of the fact that normal participation in social life involves awareness 
of unconscious urges and their rational control. Rationality is a condition for the possibility of responsible actions.

V. Lektorskiy emphasizes, that it is quite common to think that modern civilization is increasingly becoming a "civilization of knowledge", in which the production, dissemination and use of knowledge has a decisive influence on technical, economic, social and cultural processes. Scientific knowledge plays a special role in this. Knowledge, especially scientific, implies rational validity (Kuzmin, Artemenko, 2006, p. 35).

The task of modern education is not only to prepare a highly professional specialist in a particular field of science or business, but to educate a citizen with a high level of cultural thinking and speech, who understands the problems facing him, is able to solve tasks, to persuade and engage in dialogue. Achieving this goal is impossible without the formation of a high intellectual culture of a person and the ability of the individual to its further continuous improvement.

\section{REFERENCES}

Aristotel, O. (1984). On sophistic refutations. Essays: v 4 t. T. 2: Translated fron ancient Greek. Moscow, Mysl. S. 533-594. (in Russian)

Bulletin of the University of Internal Affairs (1999). Volume 9. p. 418-421.

URL: http://nbuv.gov.ua/UJRN/VKhnuvs_1999_9_93 (in Ukrainian)

Volkov, G.N. (1971). At the cradle of science, Young guard. 224 p. (in Russian) Law of Ukraine "On Education" (1997). Kyiv. t. 10, P. 168-229. (in Ukrainian) Krasnopolskaya, A. P. (2006). Sophistic argumentation: ideal and methods. Mysl. Yearbook of The Saint-Petersburg philosophical society, 6. P. 121-132. (in Russian)

Kuzmin, M. N., Artemenko, O. I. (2006). A person of civil society as the goal of education in a multi-ethnic Russian society. Question Paper for Philosophy, 6. P. 40-51. (in Russian)

Kulik, A. (2012). 10 logical mistakes of our time. The Mirror of the Week. Ukraine, Vol. 42. (in Russian)

Lektorskiy, V. A. (2012). Rationality as a cultural value. Question Paper for Philosophy, 5, P. 26-35. (in Russian)

Pavlov, V. T. (1984). The Problems of improving the teaching of logic in universities. Philosophical Thought. P. 90-98. (in Ukrainian)

Markuze, Gerbert. (1994). One-dimensional man. Moscow. 'REFL-book', 368 p. (in Russian)

Jose Ortega y Gasset. (2016). Rise of the masses; AST, 256 p. (in Russian) Platon, (2015). Dialogues. Non-Fiction. Publisher: Azbuka, 448 p.

Senchylo, A. (2010). From the history of the introduction of critical thinking in the modern educational space. Psychological and pedagogical problems of rural school: coll. of science. works of Uman State Pedagogical University named after Pavel Tychyna, Uman. Vol. 33, P. 273 - 278. (in Ukrainian) 
Sorina, G. V. (2003). Critical thinking: history and current status. Moscow University Bulletin, Series 7. Philosophy, Vol. 6. P. 97-111. (in Russian)

Sorochenko, V. (2002). Encyclopedia of Propaganda Techniques (How We Are Treated by the Media, Politicians and Advertising). URL: /http://www. psyfactor.org/propaganda1.htm (in Russian)

Sukhomlynskyi, V. O. (1977). I give my heart to children. Selected works in 5 Volumes. Radianska shkola, Vol. 3. P. 280-289. (in Ukrainian)

Sukhomlynskyi, V. O. (1976). How to raise a real person. Selected works in 5 Volumes. Vol. 2. P. 149-200. (in Ukrainian)

Titov, V. D., Tyaglo, A. V., Voropay, T. S. (1999). Critical Thinking: The Challenge of the $21^{\text {st }}$ Century World Education. Kharkiv University of Internal Affairs. 285 p. (in Russian)

Titov, V. D. (2004). Logical knowledge in its socio-cultural determination (religious, legal, political context of Antiquity and the Middle Ages). «Region-inforM». 259 p. (in Russian)

Tulchynskyi, G. L. (2009). Logical culture and freedom: logic in Russian society of 20-21 $1^{\text {st }}$ centuries. Philosophical Sciences, Vol. 4. P. 46-61. (in Russian)

Chumakov, A. N. (2012). Globalistics in the system of modern scientific knowledge. Question Paper for Philosophy, 7. P. 3-16. (in Russian)

\section{ЛОГІКО-РАЦІОНАЛЬНИЙ СКЛАДНИК СУЧАСНОГО ОСВІТНЬОГО ПРОЦЕСУ}

Ханикіна Наталія, кандидат філологічних наук, старший науковий співробітник науково-дослідної лабораторії освітології, Київський університет імені Бориса Грінченка, n.khanykina@kubg.edu.ua

Бондар Тетяна, кандидат філософських наук, доцент, доцент кафедри філософії, Київський університет імені Бориса Грінченка, вул. Маршала Тимошенка, 13-Б, м. Київ, Україна, t.bondar@kubg.edu.ua

Формування нового історичного типу особистості вимагає адекватних змін змісту освіти, засобів реалізації поставлених завдань та самої організаціі системи освіти. Досягнення поставленої мети неможливе без формування високої інтелектуальної культури людини та здатності індивіда до ї̈ подальшого постійного вдосконалення. Однак роль і місие культурно-антропологічних, і перш за все логіко-раціональних чинників у модернізаційному процесі суспільства в наш час часто недооцінюється.

У запропонованій статті наголошено на необхідності розкриття ролі логіко-раціонального складника як необхідного компоненту сучасного освітнього процесу та осмисленні шляхів вдосконалення мислительної культури засобами освіти. Зазначено про факт падіння рівня сучасної культури мислення, раціонального міркування, вміння вести конструк- 
тивні діалоги, нездатності і небажання багатьох членів суспільства до критичного аналізу ситуацій, відсутність навичок послідовного і обsрунтованого викладу власних думок, переконання своїх співгромадян раціонально-логічним способом, що може призвести до варварства. Наведені результати скорочення годин дисииплін з логіки в Університеті, щзо відобразилося на невмінні студентів встановити відношення роду і виду, причинно-наслідкових зв'язків між предметами і явищами, здійснювати класифікації. Вказано на необхідність знань логіки, яка допомагає виявити хибну інбормацію, розкрити логічні помилки.

Акцентовано увагу на важливості високої оцінки раціональності, яка веде свій початок з античності і знайшла своє вираження в античній філософиї, де філософи виходили з того, щьо тільки за допомогою розуму, тільки раціональними методами можна осягнути світ, спираючись на силу переконання, на думку.

Підкреслено роль мови як культурного феномену, який у сукупності зі свідомістю та мислиннєвими і когнітивними процесами неможливий без раціонального використання законів логіки.

Ключові слова: зміст освіти; культура мислення; логіка; логіко-раціональні засоби; освітньо-виховний ідеал; освітній процес.

Received: 02.10.2020

Accepted: 26.11.2020 